\title{
RENEGOTIATION AND PROCUREMENT $\dagger$
}

\author{
William L. Marbury* and Robert R. Bowie**
}

The Renegotiation Act is often discussed merely as a more flexible method of recapturing excessive profits from war business. But this conception of the statute, while common among many contractors and government officials, distorts it by over-emphasizing one of its aspects; the truth is that the function of the renegotiation statute is in many respects different from taxation. This article will attempt to show what those differences are and why they are important. ${ }^{2}$ To do so will require a rather full consideration of the background and origin of the law and of the conditions which have influenced its administration, but this discussion may hold some interest for its own sake as an example of how the application of a statute is molded by external conditions, practical necessities and the attitudes of those affected.

\section{Background of the Statute}

Immediately after our formal entry into war, the tempo of procurement of munitions-already strenuous-became almost frantic. From the highest quarters came mandates to the procuring agencies and the contractors with whom they dealt, to consummate pending negotiations without further delay and to undertake new negotiations before the old were completed. Program followed program with dizzying rapidity until the contracting officers despaired of ever getting contracts placed in time to meet accelerated requirements. Contractors were being asked to produce

†The opinions expressed in this article are those of the authors and are not to be taken as representing official views of the War Department.

* A.B., I92I, University of Virginia; LL.B., I924, Harvard University. Member of the Maryland Bar. Legal Assistant to the Director of Materiel, Headquarters, A.S.F., War Department.

**A.B., r93 I, Princeton University; LL.B., 1934, Harvard University. Member of Maryland Bar. Major, Army of the United States, Judge Advocate General's Department, assigned to Legal Branch, Office of the Director of Materiel, Headquarters, A.S.F., War Department.

${ }^{1} 56$ STAт. 245, 4I U. S. C. A. note prec. \$I (Supp. 1942) (Sec. 403 of the Sixth Supplemental National Defense Appropriation Act, 1942, Pub. L. No. 528, 77th Cong., 2d Sess., April 28, 1942, as amended by Pub. L. No. 753, 77th Cong., 2d Sess., October 21, 1942, Pub. L. No. 108, 78th Cong., Ist Sess., July I, I943, Pub. I. No. I49, 78th Cong., Ist Sess., July 114, 1943).

At the time this article went to press, further amendments to the Renegotiation Act wcre contained in the pending Revenue Bill of 1943 (H. R. 3687, 78th Congress, First Session, introduced November I8, 1943). In their present form, these amendments separate renegotiation to recapture excessive profits from repricing for future performance. Since it is impossible to predict whether these or other amendments will ultimately be adopted, this article does not attempt to discuss the effect of these pending amendments. It is believed, however, that they are not likely to affect the basic principles considered in the article. See concluding article in this symposium, by Jules Abels, on the pending proposals. 
items new to them or in quantities far beyond their experience. Frequently it was impossible to arrive at any reasonable estimate of production costs. Pricing was a game in which all concerned were blindfolded. ${ }^{3}$

The uncertainty as to costs made the customary fixed-price contract unsatisfactory in many cases. Fearing the consequences of too low an estimate, contractors sought prices high enough to protect themselves against any possible error. While aware of the difficulties, contracting officers were frequently reluctant to agree to prices which were likely to prove grossly excessive in the light of actual production costs. In this situation, in order to avoid prolonged negotiations and delay in production, it was vital to provide in some way for relating the compensation to be paid under the contract to the actual costs experienced in performing it. One obvious method of doing this was the cost-plus-a-fixed-fee basis of contracting, which therefore threatened to become widespread. 4 The principal objection to this form of contract was the absence of incentives to control or reduce costs. Another weighty objection was the amount of auditing and paper work it required to protect the Government's interest. ${ }^{.}$It was, therefore, essential to find some substitute for the fixed-fee contract which would not suffer from its defects. ${ }^{6}$

The problem was submitted to a committee of representatives of the War Production Board, the War Department and the Navy Department and resulted in the preparation of two contract clauses." One, known as the "redetermination clause,"

${ }^{3}$ At the hearings before a subcommittee of the Senate Committce on Appropriations, 77th Cong., $2 d$ Sess., on H. R. 6868 (hereinafter referred to as "H. R. 6868 Senate Hearings"), General Somervell, Commanding General, Services of Supply, War Department, testified, at p. 24, as follows:

"We are asking contractors to produce articles which have never been produced before. We are asking other contractors to produce articles which they have never produced before. We are asking still other contractors, who have produced articles in small quantities, to produce them in vastly larger quantities. The result of all this is that neither the contractors nor the contracting officers can make an accurate forecast of the cost of performance.

"Both parties know that there will be a period of adjustment during which costs will be high. Facilities must be converted, new facilities obtained, new personnel employed and trained to new methods, and new sources of supply developed. How long this adjustment period will last is a matter of uncertainty.

"On the other hand, assuming that the contractor is able to master the problem and to get into production, a time will come when costs will suddenly drop. When this time will come, or how far the drop will extend, it is virtually impossible to foresee. Furthermore, even when costs appear to have reached a definite level, there is no assurance of stability. Change in military strategy may cause changes in priority regulations which will affect the flow of supplies, with the result that costs will rise again. Changes in economic policy may result in increased costs of labor and materials.

"The plain fact of the matter is that in many cases it is impossible to tell, until completion of the contract, whether the contractor suffers a heavy loss, or makes a large profit."

- The use of the cost-plus-a-fixed-fee system of contracting (but not the cost-plus-a-percentage-of-cost basis) has been authorized by various statutes in connection with defense and war purchasing. See, e.g., $\$$ I (a) of Act of Aug. 7, 1939, 53 STrT. 1239, 5 U. S. C. A. $\$ 220(2) ; \$ 2(a)$ of the Act of June 28 , r940, 54 StaT. 680, $4 \mathrm{I}$ U. S. C. A. note preceding first section in title; \$I(a) of Act of July 2, r940, 54 STAT. $7 \mathrm{I}_{4}, 4 \mathrm{I}$ U. S. C. A. note preceding first section in title; and see note 6 , infra.

${ }^{5}$ See letter of U. S. Comptroller General to Hon. Louis Ludlow, 89 Cong. Rec., Jan. 14, 1943, p. A-127. Compare letter from Under Secretary of War Patterson to Hon. John W. McCormack, June 9, I941. 87 CONG. REc. 4909 (I94I).

- With certain specified exceptions, all restrictions on methods of contracting and types of contracts and contract provisions were removed by Title II of the First War Powers Act, 194I, Act of Dec. 18, 194I, 55 StAT. 838; 50 U. S. C. A. App. §6II; and Exec. Order No. 900I, Dec. 27, 194I, 6 FED. REg. 6787. See 40 Op. Atrx. Gen. No. 53 (Aug. 29, I942).

7 These clauses were first authorized for use in War Department contracts by P. B. Gen. Directive No. 31 (March 13, 1942). 
was designed to permit automatic adjustment downward in price on the basis of actual cost experience during a "test run" early in the performance of the contract. ${ }^{8}$ The other contract provision, originally known as the "renegotiation clause," was designed to permit adjustment of the price either upward or downward in the light of actual cost experience after part performance, as soon as reasonably reliable cost estimates were feasible. ${ }^{9}$ It was recognized as essential that the time for adjustment in each case should be sufficiently early in the life of the contract to retain incentives. So used, these clauses combined the main advantages of both the fixed-price and the fixed-fee contracts without their disadvantages. Under them the letting and performing of contracts were not delayed by haggling over uncertain estimates and prices; and ultimate prices were kept in line with cost experience without sacrificing the incentives of the contractor to reduce costs, at least during performance after the price was adjusted.

While the attention of the procuring agencies was thus concentrated on the development of these new forms, very large profits resulting from some of the early fixed-price contracts, under which production had already gotten under way, began to come to light. Since these profits usually reflected ignorance of costs when the contracts were made, the War Department promptly started voluntary negotiations with such contractors to adjust the contract prices to reasonable levels consistent with actual costs; and generally contractors were willing to reduce prices to those which would have been agreed to originally if similar cost experience and data had been available. In April, I942, the War Department set up a Board to handle such adjustments. ${ }^{10}$

\section{Adoption of the Statute}

However, these measures taken by the War Department to deal with such inflated profits were not permitted to develop along normal lines. As a result of the investigations culminating in the report of the Special Committee Investigating the Munitions Industry, ${ }^{11}$ published in I935, the determination had become widespread to prevent

\footnotetext{
${ }^{8}$ Briefly, the original redetermination clause required the contractor to state in the contract the cost estimates on which the contract price was based and, after performance had begun, to submit data on the cost of performance during the "preliminary run" while production was getting under way and during a test run after production became more typical. If the total costs for the "preliminary run" and for the remainder of the contract, as indicated by the test run, were less than the estimated costs on which the price was based, the price was adjusted accordingly. The revised form of this clause, authorized by the War Department Procurement Regulations for use where costs cannot be reliably estimated at the time the contract is made, is set forth in the Appendix to this article.

${ }^{0}$ This renegotiation clause required the contractor to state in the contract the cost estimates on which the price was based and to submit cost data for performance during a trial run at the beginning of the contract. On the basis of this cost experience, the parties were to renegotiate the contract price by agreement. A revised form of this clause, now called "Revision of Price by Negotiation" to distinguish it from the statutory renegotiation article, is currently authorized by the War Department Procurement Regulations for use where costs cannot be reliably estimated at the time the contract is made. It is sct forth in the Appendix to this article.

${ }^{10}$ The Price Adjustment Board was formally created by Memorandum dated April 25, 1942, from the Commanding General, Services of Supply of the War Department. After the passage of $\$ 403$, the authority of the Board was extended by Memorandum of June 30,1942 , to make the Board the agency to administer renegotiation under the statute.

${ }^{11}$ Sen. Rep. No. 944, 73d Cong., 2d Sess. (I934).
} 
a recurrence of the profiteering that had marked the conduct of the first World War. Numerous proposals had been advanced to accomplish this purpose and the desirability of legislation in some form for the limitation of profits was generally accepted. Inevitably, the publication during the early months of 1942 of reports of tremendous profits generated a strong public pressure to devise an effective method of profit control. Promptly reacting to this sentiment, during the early part of last year a number of Congressional committees began to examine into this question.12 Particular attention was paid to the possibility of special taxation on war profits and to the revival of a profit limitation in the manner of the Vinson-Trammel Act of $1934 .^{13}$ That legislation had required repayment to the Treasury of all profits in excess of a fixed percentage of the cost of production. After six years during which recovery had been hardly commensurate with the administrative expenses involved, ${ }^{14}$ the Vinson-Trammel Act had been suspended by the Second Revenue Act of $1940 .{ }^{15}$ Its revival as a means of controlling wartime profits was strongly opposed by industry and by government agencies who saw in the rigidity of its application and its requirement of cost accounting, grave threats to the war production program. ${ }^{16}$

While committees were thus investigating the whole subject of war profits, there was abruptly introduced on the floor of the House of Representatives an amendment to the Sixth Supplemental National Defense Appropriation Act, r942. ${ }^{17}$ This amendment would have forbidden the payment from appropriated funds of the final payment due under any contract, past or future, until the contractor presented a certificate of cost and an agreement "for renegotiation and reimbursement" satisfactory to the Secretary of War or of the Navy, as the case might be. ${ }^{18}$ It was apparent that this method of control was inspired by the renegotiation clause already discussed and this impression has been confirmed by Mr. Case of South Dakota who was the author of the amendment. ${ }^{19}$ Although called renegotiation, what Mr. Case

${ }^{13}$ See e.g., H. R. 6790, 77th Cong., 2d Sess. (r942), and the hearings thereon before the House Committee on Naval Affairs.

${ }^{13}$ Act of March 27, r934, 48 STAT. 504, 34 U. S. C. A. $\$ 496$, as amended by Act of June 25, 1936, 49 Stat. 2926, 34 U. S. C. A. \$496; Act of April 3, 1939, \$I4, 53 STAT. 560, 10 U. S. C. A. \$\$3II, 3I2, 34 id. $\$ 496$; Act of June $28,1940,54$ STAт. 676,4 I U. S. C. A. note preceding first section in title; and Act of Sept. 9, 1940, 54 STAT. 883,4 I U. S. C. A. note preceding first section in title.

Is The total amount assessed under the Act up to Sept. 30, 1942, was approximately $\$ 7,500,000$. See Hearings before the subcommittee of the Senate Committee on Finance on Renegotiation of Contracts, Sept. 29-30, 1942, 77th Cong., 2d Sess., pp. 94-98.

${ }^{20}$ See Act of Oct. 8, I940, 54 STAт. I003, 34 U. S. C. A. $\$ 496 a, 46$ id. $\$$ rr 55 a.

${ }^{10}$ See testimony of Under Secretary Patterson and Mr. Donald M. Nelson, Chairman of the War Production Board, at the Hearings before the House Committee on Naval Affairs on H. R. 6790, 77th Cons., 2d Sess. (I942) 2473-2475, 2577-2578.

1788 Cong. Rec., March 28, 1942, p. 3230.

${ }^{18}$ The exact words of the proposed amendment were as follows: "Sec. 402-A. No part of any appropriation contained in this act shall be available to pay that portion of a contract for construction of any character and/or procurement of material and supplies for either the Military or Naval Establishments designated as 'final payment' until the contractor shall have filed with the procuring agency a certificate of costs and an agreement for renegotiation and reimbursement satisfactory to the Secretary of War or the Secretary of the Navy, as the case may be."

${ }^{10}$ See 88 Cong. Rec., March 23, 1942, p. 3228. Another factor prompting the proposal was the decision in the U. S. v. Bethlehem Steel Corporation, 315 U. S. 289 (1942). 
proposed was apparently that the profit to be paid any contractor should be determined by the Government after performance and in the light of costs.

Inasmuch as this proposal involved administrative action, it was subject to a point of order which was promptly made. ${ }^{20}$ Its author thereupon offered an amendment which substituted for the discretion of the contracting officer an arbitrary percentage profit limitation, but of what did not appear. ${ }^{21}$ As thus modified his amendment was adopted without debate and by an overwhelming vote. ${ }^{22}$

The procurement agencies immediately protested. Hearings were held before the Subcommittee on Appropriations of the United States Senate at which their objections to the Case amendment were forcibly stated. ${ }^{23}$ The attention of the Committee was called to existing administrative practices designed to prevent excessive profits. The so-called "renegotiation" and "redetermination" clauses were described and their use in preventing excessive profits was explained. Reference was also made to the fact that an administrative agency had just been created within the War Department to bring about voluntary reductions in contract prices where a study of the overall profits of a contractor indicated that he was being paid too much for his products. The Committee was told of one example where a voluntary reduction of contract price had been agreed upon which was expected to save the Government $\$ 40,000,000$.

As the hearing progressed it became apparent that some sort of legislation to control profits was inevitable. At the request of the Chairman of the Committee the procurement agencies drafted a substitute for the Case amendment. This substitute read as follows:

I. The Secretary of War is directed to insert in any contract hereafter made by the War Department, which, in his judgment, may result in an excessive profit to the contractor, a provision for the renegotiation of the contract price at a period when the profits can be determined with reasonable certainty.

2. The Secretary of War is directed, whenever in his opinion excessive profits have been realized, or are likely to be realized, from any contract with the War Department, to require such contractor to renegotiate the contract price. This provision shall be applicable to all contracts hereafter made and to all contracts heretofore made, whether or not such contracts contain a renegotiation clause, provided that final payment has not already been made pursuant to such contract.

3. In renegotiating a contract price the Secretary of War shall not make allowance for any salaries, bonuses, or other compensation paid by the contractor to its officers or employees, in excess of a reasonable amount, nor shall he make allowance for any excessive reserves set up by the contractor, and the Secretary of War shall freely use the powers of audit conferred upon him by existing law for the purpose of ascertaining whether such

2088 Cong. Rec., March 28, 1942, p. 3230.

${ }^{21}$ Ibid. The text of the substitute amendment was as follows: "Sec. 402-A. No part of any appropriation contained in this act shall be available to pay that portion of a contract for construction of any character and/or procurement of material and supplies for either the Military or Naval Establishments designated as 'final payment' to any contractor who fails to file with the procuring agency a certificate of cost and an agreement for renegotiation of contract and reimbursement of profits in excess of 6 percent."

${ }_{22}^{2}$ The record shows that the vote stood-ayes 70 , noes 8 . Id. at 3231 .

${ }^{23}$ H. R. 6868 Senate Hearings, 22-30, 35-49, 83-92, $21 \mathrm{r}$. 
unreasonable compensation has been or is being paid, or whether such excessive reserves have been set up.

4. In addition to the powers conferred by existing law, the Secretary of War shall have the right to demand of any contractor who holds uncompleted contracts with the United States for the production of war materials in the aggregate amount of $\$ 500,000$ or more statements of actual costs of production and such other financial statements, at such times and in such form and detail as the Secretary of War may require.

5. The authority and discretion herein conferred upon the Secretary of War may be by him delegated to such individuals or agencies in the War Department as he may designate and he may authorize such individuals to make further delegations of such authority and discretion.

6. The foregoing provisions shall be applicable to the Secretary of the Navy in the case of contracts with the Navy Department, and to the Chairman of the Maritime Commission in case of contracts with that Commission. The powers conferred by paragraph 4 above shall be exercised by the War Department, the Navy Department, or the Maritime Commission, whichever holds the largest aggregate amount of uncompleted contracts for the production of war materials. ${ }^{24}$

While this proposal bore the marks of hasty preparation and was somewhat lacking in inner consistency, it was reasonably clear on the following crucial points:

(a) Except where otherwise provided by the insertion in the contract of a specific provision, any renegotiation was apparently intended to apply primarily to amounts remaining unpaid under the contract.

(b) The insertion of the renegotiation clause in a contract was left wholly discretionary with the head of the procuring agency.

(c) Any renegotiation either under a renegotiation clause or otherwise, was to be a genuine renegotiation without power in the Government to compel adjustment.

(d) Any renegotiation was to be conducted during the life of the contract.

But this proposal of the Departments was radically altered by Congress, and as finally enacted, Section 403 of the Sixth Supplemental National Defense Appropriation Act, I942, differed from the proposal on all of these points.

(a) It provided for the recapture of profits already paid to the contractor and found to be excessive as a result of renegotiation whether conducted under a contract provision or otherwise.

(b) It made mandatory the insertion in any contract in excess of $\$ 100,000$ of a clause calling for renegotiation of the contract price.

(c) It contained language which has been widely construed to confer upon the Government the power to compel adjustment where the agreement of the contractor cannot be obtained. ${ }^{25}$

24 Id. at 84 .

${ }^{25}$ Subsection 403 (a) containing the definitions, provides that "the terms 'renegotiate' and 'renegotiation' include the refixing by the Secretary of the Department of the contract price." See the discussion in Rentegotiation of War Contracts, Nat. Assn. MFrs., Law Dep't Bull. (Aug. 26, 1942) 4. Compare the statements on this question in the debates in the Senate. 88 Cong. Rec., April 23, I942, at pp. 3763-3771 and $3773-3776$. 
(d) It provided that renegotiation, whether effected under the contract provision or otherwise, might take place at any time up until three years after the termination of the war.

\section{Early Administration of the Statute}

The full significance of the changes that Congress had made in the procurement agencies' proposal soon became apparent. Up until April, 1942, the renegotiation of contract prices was an integral part of the procurement process. Whether or not renegotiation was conducted under a so-called "renegotiation" clause, the objective was the same-the adjustment of the contract price to a figure which would have been regarded as reasonable at the time of the original negotiation, had the facts been available to the parties. Furthermore, such a negotiation was in every instance undertaken during the lifetime of the contract at a time when the incentives of a fixed-price method of contracting could still have sufficient scope within which to operate. It is true that under the "renegotiation" clause, price adjustments might be retroactive to the beginning of the contract. In almost no case, however, was recapture of profits the primary result, although in some cases payments for units thereafter delivered might be greatly reduced as a result of excessive payments previously made.

Renegotiation as conducted under the statute, on the other hand, took on a different aspect. This was principally due to the fact that renegotiation was applicable to all contracts and subcontracts and could be required after the contract affected had been completed. As generally construed by contractors and their counsel, the statute rendered contractors liable, until three years after the war, to be called upon to refund such part of any profits earned by them on their war contracts or subcontracts as the head of the procuring agency or his delegates might see fit to require, and this liability would continue until any contract subject to renegotiation had been finally dealt with. This situation presented a serious dilemma. The natural hesitancy of contractors to make contracts which would subject them to a liability undetermined in amount and indefinite in duration threatened to impede the procurement program. Since it was obviously impossible to examine and renegotiate individually the prices of all contracts-and subcontracts subject to the statute within any reasonable period, some other means for disposing of this potential liability with reasonable promptness had to be found.

To avoid this impasse, there was developed the method of "overall" renegotiation. Under this procedure the contractor's profits on its entire war business for a specified fiscal period were examined in order to reach an agreement for eliminating excessive profits on the contracts as a group, and an agreement made covering the period involved. ${ }^{26}$ In addition to giving contractors clearance with reasonable promptness, this method had several other important advantages. By dealing with all contracts together, cost accounting and the allocation of costs were reduced to a minimum, and time was saved for both contractors and the Government. Furthermore, this method

\footnotetext{
${ }^{26}$ A full statement of the detailed procedures will be found in "Principles, Policies and Procedures to be Followed in Renegotiation" published by the War Department Price Adjustment Board.
} 
permitted contractors to offset losses on any war contracts against profits from other war contracts during the same period.

By its very nature, however, overall renegotiation tended more and more toward recapture of past profits rather than refixing of prices for future periods. Since it was based on the fiscal year of the contractor it was more convenient to postpone renegotiation until the usual financial statements for the period had been prepared. In addition, because of the difficulty of forecasting profits before the end of the fiscal period, contractors preferred to postpone a settlement until their profits were known. For the same reason, government officials, especially in the beginning, hesitated to give a clearance to the contractor for a future period on the basis of predictions. Administered in this way, the law was in effect a tax of $100 \%$ on all profits from war business, which the procuring agencies regarded as excessive, and was wholly different from the procedure for revising contract prices after part performance, which had inspired the statutory scheme. In fact, when contracting officers desired to provide for such individual price revision, they asked permission to use the old form of contract renegotiation clause, in addition to the statutory provision. Thus, many contracts now exhibit the paradox of two renegotiation clauses substantially similar in wording, but wholly different in their practical operation. This curious practice illustrates dramatically the extent to which statutory renegotiation on an overall basis had departed from the actual adjustment of contract prices, and indicates that renegotiation under Section 403 as practiced during the early months of its operation, was merely a discretionary excess profits tax of $100 \%$.

Before this interpretation of the statute had become settled, however, other powerful forces were in motion to shift the emphasis in its administration. The first of these forces was the drive to prevent inflation. When in the spring of last year the Office of Price Administration expanded its price regulations to cover practically the entire economy by issuing its General Maximum Price Regulation ${ }^{27}$ and its machinery regulation-MPR No. $136^{28}$-a serious problem was presented in connection with military procurement. While a great many of the articles procured by the Army were already under price regulation, its extension to the strictly military items which were subject to frequent changes would have required elaborate formulas for flexible regulation. In an effort to avoid the divided authority and complexity which would have resulted from the establishment of such price control by the Office of Price Administration, the procuring agencies were obliged to develop other means which would accomplish the desired result of controlling inflation in this field. ${ }^{29}$ Mere recapture of past profits by renegotiation under Section 403 did not serve this

${ }^{27}$ Issued April 28, 1942, 7 FED. REG. 3153, effective May II, 1942. Effective date as to sales or deliveries to or contracts with the War Department postponed to July I, 1942, by Supplementary Regulation No. 2, issued May 9, 1942, id. 3489. Combat and certain other military items exempted by Supplementary Regulation No. 4, issued May 13, 1942, id. 3724 .

${ }^{28}$ Issued April 28, 1942, 7 FED. REG. 3198. Originally effective May 18, 1942, postponed to June 1 , 1942, by Amendment No. 2, May 14, 1942, id. 3723, and to July I, I942, by Amendment No. 3, May 29, I942, $i d$. 4I76. Revised and re-issued June 30,1942 , id. 5047 , to become effective July 22 , I942.

"9PA Second Quarterly Report (I942) 39-45. 
purpose. While this would stop the flow of dividends to stockholders, it operated too late to.protect the economy from inflationary expenditures for manpower and materials. In fact, administration of the statute as a taxing measure confined to the recapture of profits earned in the preceding fiscal year may tend to stimulate inflation by taking the pressure off the procurement officers to negotiate a proper price at the inception of the contract and by lessening the incentive of the contractor to reduce his costs. What was needed was more effective control of prices for the future, to prevent excessive profits from accruing at all.

The second of these influences was created by the shortages of critical materials and manpower which were then beginning to become serious. To maintain the greatly accelerated production of war materials, and make most effective use of our available resources, it was recognized that all producers must operate at their highest efficiency with the minimum waste of labor and materials. Since economic pressure on price has been the traditional way of evoking such efforts to reduce costs, it was natural that attention should turn toward closer pricing as a means to conserve labor, materials and facilities. ${ }^{30}$ When that objective had become crystallized, the procuring agencies gradually became aware that the policies and methods followed for profit control would largely determine the success or failure of the program. Real incentives on the part of contractors to reduce their costs in order to increase their profits can hardly be maintained if all the profits will be taken from them on renegotiation. On renegotiation to recapture past profits, this tendency can be overcome to some extent by allowing a higher rate of profit for more efficient producers, ${ }^{31}$ but this is only a partial solution to the problem. Accordingly, some other method was needed.

While these pressures for narrowing the field of recapture as far as possible and for relying more heavily on purchase and price control were developing, the statute was under direct attack from another quarter. Representatives of industry objected that renegotiation for the recapture of past profits was merely a delegation without standards of the power to tax profits from war business and was an unjustified departure from established principles of taxation. Accepting this view, prominent members of the Senate Committee on Finance urged the outright repeal of the statute. 32

\footnotetext{
${ }^{30}$ See note 45, infra.

${ }^{31}$ See War Department Manual for Renegotiation, pars. 421, 422.

${ }^{32}$ See Hearings before the Senate Committee on Finance on the Revente Act of 1942, 77th Cong., and Sess., Vol. I, p. 98I. The following took place:

"The Chairman. (Senator George) I think there is a great deal in what you say, and ultimately the Congress will repeal that renegotiation-of-contract provision, because it has been found that it will be utterly unworkable.

"Senator Taft. Mr. Chairman, I think it ought to be repealed in this bill.

"The Chairman. I think in doing that there should be an over-all limitation on profits on war contracts, both prime contracts and subcontracts, over the whole period, so that there could be no unconscionable profiteering out of the war.

"Mr. Fernald. That would be profits after what has already been taken by taxes.

"The Chairman. Yes; an over-all limitation on the war profits directly. I think you can very well leave the excess-profits tax to operate on all non-war profits anyway.

"Mr. Fernald. I think you have gotten it to operate pretty well on the war profits as well, sir. I am not very much disturbed about that.
} 
The result of all these factors was to bring back to the surface the conception of renegotiation as a method of price control-a conception which had to a large extent been submerged in the actual administration of the statute. At the same time there were serious objections to an abandonment of the procedure which had been developed under the statute. It was forcefully argued that price adjustment without recapture might fail to eliminate excessive profits in some cases and there was always the strong probability that if recapture were completely abandoned and excessive profits did result, Congress would adopt a flat profit limitation which would create serious obstacles to procurement. How to develop the statutory process as an effective control of inflation, and as a means of saving manpower and materials, without creating once again the conditions which had led to its original enactment, was the problem.

\section{AMENDMENT OF the Statute}

The matter was brought to a head when the Chairman of the Senate Committee on Finance proposed to substitute for renegotiation an entirely new law imposing a flat limitation on profits after taxes. ${ }^{33}$ In consequence hearings were held at which the entire position of the statute was carefully analyzed: ${ }^{34}$ The War Department, the Navy Department, the Treasury Department and others gave their views on the function and administration of the statute. While recognizing the shortcomings of renegotiation for recapture, the Departments repeated with emphasis the objections to the substitution of a flat profit limitation which they had originally voiced when the statute was first under consideration. Stressing the importance of controlling costs as well as profits and of maintaining incentives for efficiency, ${ }^{35}$ they pointed out the relation of the renegotiation statute to these objectives, and the need for increased emphasis on this aspect of the problem. To facilitate the administration of the statute, especially as a means of price control, the Departments offered a number of amendments. Of these changes, some were merely intended to clarify the statute and to correct obvious deficiencies, but others were designed to permit a shift from recapture to price control in the administration of the statute. ${ }^{36}$ These proposals for revising the statute were adopted by Congress as Section 8or of the Revenue Act of $1942 .^{30^{2}}$

"The Chairman. It is not the renegotiation, it is the uncertainty involved, and the long time in which those renegotiations will be going on, and the constant change of personnel at the head of divisions working it out, leads to so many complications until certainly at some time during this war, if the war goes on for another year or two, we are going to have to deal with that question. It is very proper to say it should be dealt with."

The fact that the pending Revenue Act of 1942 included the new Excess Profits Tax led many who viewed renegotiation primarily as a tax measure to feel that it was no longer needed and should therefore be repealed.

${ }^{33}$ See Hearings before the Senate Committee on Finance on Section 403 of Public Law 528, 77th Cong., $2 d$ Sess., Sept. 22-23, I942, p. 60.

3. Ibid.; and Hearings before the subcommittee of the Senate Committee on Finance on Section 403 of Public Law No. 528, 77th Cong., 2d Sess., Sept. 29 and $30,1942$.

\footnotetext{
${ }^{85}$ Id. at $7,19-20,92-93$.

${ }^{30}$ Id. at $5 \mathrm{I}-53, \mathrm{I} 47-\mathrm{I} 49$.
}

${ }^{30 a}$ Act of Oct. 21, 1942, Pub. L. No. 753, 77th Cong., 2d Sess., 56 STat. 798. 
With the amendments designed to perfect the statute as a means of recapture of excessive profits we are not here concerned, but other changes are significant for the present study. One of these conferred upon the Secretary the discretionary power to exempt from renegotiation any contract or subcontract under which the profits can be determined with reasonable certainty when the contract price is established. ${ }^{87}$ The full use of this power would permit the Secretary to exclude from renegotiation large numbers of contracts and subcontracts under which prices are known to be fair when the contract is made, and thereby to ease the administrative burden. Similar in its effect was the exemption of contractors and subcontractors whose total war business did not exceed $\$ 100,000$ for their fiscal year. ${ }^{38}$ Another equally important provision is the discretionary power to exempt from some or all of the provisions of Section 403, as amended, the performance under any contract or subcontract during a specified period or periods and to provide that the contract price in effect shall not be subject to renegotiation if, in the opinion of the Secretary, the provisions of the contract or subcontract are otherwise adequate to prevent excessive profits. ${ }^{30}$ For example, where the contract contains other provisions for price adjustment or profit limitation which the Secretary considers adequate, he may exempt it from statutory renegotiation and from profit recapture. A further amendment to the statute expressly authorizes the Departments upon renegotiation to grant clearances for future as well as past periods, thereby making it possible to exempt some or all of the contracts or subcontracts of a contractor for a specified future period.40 Still another amendment authorizes the contract article for renegotiation to specify the time within which renegotiation will be held. ${ }^{41}$ This would allow the Secretary to limit renegotiation to the life of the contract if he so desires.

These amendments provide the means for a return to the prestatutory conception of renegotiation. Without requiring abandonment of retroactive recapture of excessive profits, they afford an opportunity for a shift of emphasis to prospective pricing. If this opportunity is fully exploited, renegotiation can again become a more

${ }^{37}$ Section 403 (i) (2) (ii) enacted by $\$ 80 \mathrm{r}$ of the Revenue Act of $1942 ; \$ 403(\mathrm{i})$ (2) reads as follows:

"(2) The Secretary of a Department is authorized, in his discretion, to exempt from some or all of the provisions of this section-

(i) any contract or subcontract to be performed outside of the territorial limits of the continental United States or in Alaska;

(ii) any contracts or subcontracts under which, in the opinion of the Secretary, the profits can be determined with reasonable certainty when the contract price is established, such as certain classes of agreements for personal services, for the purchase of real property, perishable goods, or commodities the minimum price for the sale of which has been fixed by a public regulatory body, of leases and license agreements, and of agreements where the period of performance under such contract or subcontract will not be in excess of thirty days; and

(iii) a portion of any contract or subcontract or performance thereunder during a specified period or periods, if in the opinion of the Secretary, the provisions of the contract are otherwise adequate to prevent excessive profits. types."

"The Secretary may so exempt contracts and subcontracts both individually and by general classes or

${ }^{38}$ Subsection (c)(6) of $\$ 403$, as amended by Rev. Act of $1942, \$ 801$.

${ }^{39} \$_{403(b)}$ and $\$ 403(\mathrm{i})(2)$ (iii) enacted by Rev. Act of 1942, \$201. See note 37 , supra.

${ }^{10} \$ 403(\mathrm{c})(4)$ enacted by Rev. Act of $1942, \$ 80 x$.

“ $\$ 403(\mathrm{~b})$, as amended by Rev. Act of $1942, \$ 801$. 
integral part of the procurement process and the need for recapture will be greatly reduced. The legislative history of the amendments makes it clear that Congress recognized the importance of using renegotiation as an instrument of price and cost control, and intended to provide tools for making the transition to that basis as rapidly as conditions would allow. ${ }^{42}$

With the need for developing a closer relation between profit control and the maintenance of incentives for efficiency and cost control thus accepted, it remains to be seen how far the amendments included in the Revenue Act of 1942 will be used for this purpose. The limited cost data and experience available for many types of war materials, and the wide variations amiong producers all create difficulties which make for adherence to the method of recapture. However, the War Department has made the first effort at general use of the powers granted by the amendments. On January 2, I943, it authorized the use in War Department contracts of two new clauses providing for periodic price adjustment with provision for exemptions from renegotiation. ${ }^{43}$ Both of these articles divide performance under the contract inte specified periods of three to six months for the purpose of adjusting the contract price at regular intervals. Under the first form the contract price originally fixed for the first period of performance is exempt from statutory renegotiation. At the end of that period the contractor submits cost data for the preceding period and cost and price estimates for the next period, and the contracting officer and the contractor negotiate to fix a price for the succeeding period under the contract. If the contracting officer is satisfied that the cost data are reliable and that the contract price fixed for the next period is fair to the Government, he may exempt the price from renegotiation. The same procedure is followed at the end of each succeeding period under the contract. except the last. The second form of article is designed for cases where cost informa tion is not sufficient at the beginning of the contract to fix a firm price. Under this form, the price for the first period is adjusted at the end of that period and appropriate credit or refund made; otherwise this article is similar to the first form.

These clauses combine various features designed to obtain close prices while retaining incentives for efficiency. ${ }^{44}$ Since the periods for which prices are fixed are relatively short, uncertainty and the risk of future changes in conditions are reduced and the need for allowances for contingencies should be correspondingly decreased. At the end of each period, prices for the next period can be fixed on the basis of

\footnotetext{
62 The relation between profit and cost control was strongly re-emphasized by the President in his 1943 Budget Message in the following words:

"The procurement program must achieve maximum production with minimum waste and with the speed essential in time of war. This is the controlling objective not only for the original negotiation of contracts but also for the renegotiation required by law. The law provides for the prevention or recapture of excessive profits, thus supplementing and reinforcing the objectives of the excess-profits tax. I believe that control of the costs of production is of equal importance.

"The proper negotiation and renegotiation of contracts must strive to reconcile the avoidance of excessive profits, with the maintenance of incentives to economical management." (Italics added).

${ }^{43}$ Memorandum No. S-5-1-43, Jan. 2, 1943, War Dep't, Services of Supply, now included in War Dep't Procurement Regulations as pars. 360.1 and 360.2 of P.R. No. 3 and Section IV of Procurement Reg. No. 12. One of these forms is set forth in the Appendix to this article.

Ibid.
} 
recent experience, current conditions and more accurate forecasts. If a firm price exempt from statutory renegotiation is granted, the contractor is enabled to increase his profit by managerial skill, improved methods and efficiency in operation. Finally if costs are reduced in one period through efficiency, then when the prices are adjusted for the succeeding period, the Government will benefit from the reduced costs in the form of lower prices but the contractor will enjoy a higher profit margin.

Despite these advantages the clauses are not a complete solution and have significant drawbacks. Their successful operation requires considerable production experience and reliable cost data to provide the basis for negotiations at the end of each period. They can therefore be used only if the contractor has an adequate cost accounting system. Again they are suitable only for larger contracts where the time spent in preparing the necessary cost information and in negotiating at the specified intervals will not be out of proportion to the amounts involved.

Nevertheless, these clauses are a beginning in the direction of closer price control to prevent the necessity for recapture of past profits. While the extension of this approach will depend on knowledge gained in the use and operation of these articles, on accumulation of production and cost information, and on improved techniques for its use in contract negotiation, the experience of our enemies as well as our allies in waging total war clearly teaches that closer pricing must ultimately be relied on in the interest of higher efficiency and lower costs. ${ }^{45}$

${ }^{45}$ See for discussion of this foreign experience, 7 Foreign Commerce WeEkry (U. S. Dep't of Commerce) No. 4, May 2, 1942, pp. 6-7; Withrow, The Control of War Profits in the United States and Canada (1942) 91 U. of PA. L. Rev. 194; Fourth Report from the Committee on National Expendtores, (Great Britain, I940-r94I); First Report from the Commitree of Public Accounts (Great Britain, July 2x, 1942). The British policy is well stated in a memorandum prepared by the (British) Treasury on the "Excess Profits Tax and Contract Policy," and printed as an Appendix to the Finst Repont from the Commtree of Public Accounts, supra. Pertinent excerpts are as follows:

" 2 . In the course of the present inquiry into the prices, and outcome, of certain fixed price contracts, the suggestion has been made by certain of the contractors who have been examined by the Committee that the emergence of a high profit from war contracts is of no advantage to the contractor and does not matter to the State, because after deduction of taxation the contractor is left with a small margin of profit only. The suggestion has also been made that for the same reason the contractor has no incentive to aim at unreasonably high prices, since the profit emerging from such prices would go back to the State in taxation.

"3. There is also an implication arising from these suggestions that the investigation of costs for the purpose of arriving at contract prices (whether fixed price or not) is an unnecessary cxpenditurc of effort. ...

"II. But the matter is far from being solely one of profit margins. The aim of the State in dispensing the taxpayers' money is to obtain the stores which it requires at the lowest reasonable pricc.

" 12 . The best method of securing this end is to give the contractor an incentive to produce at low cost; and the best form of contract for this purpose is the fixed price contract provided that there arc sufficient data upon which to assess a reasonable fixed price. If, for any reason, a fixed price contract is not feasible, recourse must be had to some form of costed contract. Though it is more difficult in this case, to provide an incentive to efficient and low cost production, a costed contract can prevent the inclusion in costs of expenditure which the Department is in a position to disallow (c. g. cxtravagant remuneration to directors, loading of price with overheads irrelevant to the production undertalien for the Government, or wages beyond a recognized level). But more than this, cost investigation may well reveal facts which show that uneconomic methods of production are being practised, and these can be followed up by the Department, with a view to a suitable remedy.

"r3. If, however, the price of stores supplied to the Government were left uncontrolled, except for the automatic operation of E. P. T., there would be no effective deterrent to unwarranted rises in cost of whatever kind. The machinery of the Inland Revenue is not intended, nor is it adapted in the same way 
In recognition of this, the objective of closer pricing is receiving increasing emphasis in the actual administration of renegotiation. In determining excessive profits for a past period, the pricing policies and records of the contractor during the period are carefully considered in order to reward the fixing of sound prices and the elimination of undue reserves against contingencies in the first instance. Since large loadings in original prices remove most of the risks in performance of the contract, the contractor is entitled to a smaller rate of profit than one who makes close prices and takes the risk of possible losses. ${ }^{46}$ Directly related is the policy of requiring price reductions on future deliveries as a part of renegotiation. ${ }^{47}$ Such price adjustments are now receiving more and more attention in renegotiation and presumably this trend will increase as the renegotiating agencies become more current in their work.

By attempting to fix close prices in the first instance and eliminating large reserves or loadings for contingencies, and by keeping and making available adequate cost records to provide the basis for sound negotiation, industry can speed this trend and help to substitute well-negotiated original prices for retroactive renegotiation; and to obtain the benefits to Government and industry of normal incentives in the reduction of costs.

\section{APPENDIX \\ War Department Price Adjustment Contract Articles}

I. Redetermination:

Article -. Redetermination of price by formula.

(a) Agreement to redetermine price. The Government and the Contractor recognize that the costs of performing this contract cannot be accurately estimated at the time of its execution, and that the price fixed in Article - may therefore be too high. They therefore agree that the contract price fixed in Article - shall be redetermined in accordance with this Article on the basis of the actual experience of the Contractor in performing part of the contract. They agree that the cost of producing the first - $\%$ of the items called for hereunder (hereinafter called the "preliminary run") will not necessarily be typical for the remainder of the contract. The cost of producing the next $-\%$ (hereinafter called the "test run") shall therefore be used as the general basis for the redetermination of price.

(b) Estimate of costs. The Contractor represents that the contract price fixed in Article - is based on a total estimated cost of $\$ \ldots \ldots \ldots$, itemized as follows: 1

A. Factory Cost

I. Direct materials.

2. Direct productive labor.

3. Direct engineering labor.

4. Miscellancous direct factory charges.

5. Indirect factory expenses 2 (State basis of allocation). Total Factory Cost

B. Other manufacturing cost.

C. Miscellaneous direct expenses.

as the machincry of the Contracting Departments, to analyze costs of production and check unnecessary expenditure; nor could it reveal, as investigation by Contracting Departments can reveal, the existence of uneconomic or wasteful methods of production."

"O War Departarent Manual for Renegotiation, pars. 423, 426.3.

${ }^{47}$ Ibid., pars. 440 to 446 .

1 This breakdowin may be altered to suit particular circumstances. Any reserves for contingencies should be stated separately and clearly identified.

a State separately the estimated amount of each of the following items included:

(a) Normal depreciation.

(b) Special amortization. 
D. Indirect engineering expenses.

E. Expenses of distribution, servicing and administration.

F. Guarantee expenses.

(c) Cost statements.

(r) Within ... days after the completion of the production of the "test run" the Contractor shall submit to the Contracting Officer the following data:

(i) Separate statements showing the costs of producing the "preliminary run" and the "test run" itemized in the same way as the estimated cost stated in section (b) above;

(ii) Estimates of the cost of producing the items to be delivered during the remainder of the contract based upon the previous cost experience of the Contractor and upon all other relevant factors; and

(iii) Proposed revised prices under the contract.

(2) The Contractor will maintain books, records and accounts so as to reflect accurately and segregate clearly the costs of performing this conuract during the "preliminary run" and "test run." For this purpose the Contractor may follow the cost accounting system regularly used by it, if the Contracting Officer finds it is adequate and in accordance with sound accounting practice. The statements showing costs experienced by the Contractor under this contract shall be based upon such books, records and accounts and shall be certified as correct by two officers of the Contractor or by an independent public accountant. The Contractor shall submit his books, records and accounts to such examination and audit as the Contracting Officer may request.

(d) Method of redetermination.

(I) Upon the filing of the data required by Section (c) hereof, the Contracting Officer and the Contractor shall determine the costs of producing the "preliminary run" and the "test run" and the cost of producing the remainder of the items called for by the contract as indicated by the cost of production of the "test run" and the cost estimate submitted by the Contractor under Section (c). Any disagreement as to the experienced costs or estimated costs shall be subject to Article - (Disputes).

(2) If the cost of producing the "preliminary run" and the "test run" plus the cost of production of the remainder of the items called for by the contract as determined under subsection ( $I$ ) above, is less than the total estimated cost stated in section (b), the total price to be paid pursuant to Article - shall be reduced by the amount of the difference. The redetermined price shall be evidenced by a supplemental agreement.

(e) Payment. Pending the redetermination of the contract price hereunder the Government shall pay for all items delivered hereunder at the price fixed in Article - Upon the redetermination of the price hereunder the Contractor shall apply as a credit against payment for subsequent deliveries or shall repay to the Government, as the Contracting Officer may direct, an amount equal to the difference between the price paid on all items theretofore delivered and the redetermined price for such items; and the Government shall pay for all items thereafter delivered the redetermined price minus any such credit. If, before the price is redetermined hereunder, any amount paid under this contract has been included in any renegotiation agreement made under Section 403 of the Sixth Supplemental National Defense Appropriation Act, 1942, as amended, no refund or credit shall be required hereunder with respect to that amount.

(f) Renegotiation. Any redetermination of the contract price made under this Article is without prejudice to the determination of any excessive profits of the Contractor upon subsequent renegotiation under Section 403 of the Sixth Supplemental National Defense Appropriation Act, 1942, as amended, or the contract article inserted herein pursuant to the Act.

\section{Revision by Negotiation:}

Article - Revision of entire price by negatiation.

(a) Agreement to revise price. The Government and the Contractor recognize that the costs of performing this contract cannot be accurately estimated at the time of its execution and that the contract price fixed in Article - may therefore be either too high or too low. They therefore agree that the contract price shall be revised upward or downward in accordance with this article on the basis of actual experience of the Contractor in producing - $\%$ of the items under this contract (hereinafter called the "trial run"). They recognize that the costs of performing that part of the contract will not be typical for the remainder of the contract, but will provide sufficient information and experience to permit revision of the price.

(b) Estimate of costs. The Contractor represents that the contract price fixed in Article - is based on a total estimated cost of $\$ \ldots \ldots \ldots \ldots \ldots$ itemized as follows: [The breakdown of items, including footnotes, is identical to that in paragraph (b) of the Redetermination Article, supra. ED.] 
(c) Cost statements.

(I) Within - days after the completion of the trial run, the Contractor shall submit to the Contracting Officer the following data: ${ }^{3}$

(i) Separate statements showing costs of production for the trial run, itemized in the same way as the estimated cost stated in section (b) above.

(ii) Estimates of the cost of producing the items to be delivered during the remainder of the contract based upon the previous cost experience of the Contractor and upon all other relevant factors.

(iii) Proposed revised prices under the contract.

(2) [This sub-paragraph is identical to sub-paragraph (c)(2) of the Redetermination Article, supra, except that it omits the last 7 words in the first sentence therein. Ev.]

(d) Negotiation for revision.

(r) Upon the filing of the data required by section (c) hereof, the Contractor and Contracting Officer shall negotiate in good faith to agree upon revised prices under this contract. The revised price may be different for different periods of the contract and may be in excess of or less than the price stated in Article - hereof. The agreement reached shall be evidenced by a supplemental agreement to this contract stating the revised price under the contract.

(2) If the Contracting Officer and Contractor fail to agree on revised prices under the contract within thirty days after the date for filing of the data by the Contractor under section (c) hereof, or such further period as may be fixed by agreement, the Contractor, if not in default, or the Government, may terminate the contract hereunder by written notice delivered within ten days after the expiration of said thirty-day period or extension. Upon such termination by either party, the rights and obligations of the parties shall be governed by the provisions of Article - hereof ("Termination for the Convenience of the Government"), except that the Contractor shall be allowed no profit for any uncompleted portion of the contract. If revised prices are not agreed upon and the contract is not terminated, the Government shall pay to the Contractor the price fixed in Article - for the remainder of the contract.

(e) Payments. Until the contract price is revised hereunder, the Government shall pay to the Contractor the price set forth in Article - for all articles delivered. If the contract price is revised upward hereunder, the Government shall pay to the Contractor the difference between the prices paid on all items theretofore delivered and the revised price for such items. If the contract price is revised downward hereunder an amount equal to the difference between the price paid on all items theretofore delivered and the revised price for such items, shall be applied as a credit against payments for subsequent deliveries or shall be applied in such other manner or repaid to the Government, as the Contracting Officer may direct. For all items delivered after any price revision hereunder, the Government shall pay the contractor the revised price, minus any such credit. If, before the price is redetermined hereunder, any amount paid under this contract has been included in any renegotiation agreement made under Section 403 of the Sixth Supplemental National Defense Appropriation Act, 1942, as amended, no refund or credit shall be required hereunder with respect to that amount.

(f) Renegotiation. Any revision [this paragraph then follows paragraph (f) in the Redetermination Article, stipra. ED.]

\section{Periodic Adjustment with Exemption from Renegotiation:}

Article - Periodic adjustment of price.

(a) Price periods. The Government and the Contractor agree to adjust the contract price under this contract periodically in accordance with this Article and agree that the performance under this contract will be divided into successive periods for that purpose. The first period will extend from - to -; and the second and each succeeding period will extend for - months from the end of the preceding period.

(b) Estimates and prices for first period.

(I) The Contractor and the Government have agreed upon the following estimate of costs for the items to be delivered during the first period hereunder: [The breakdown of items, including footnotes, is identical to that in (b) of the Redetermination Article, supra. Ev.]

(2) The Contractor and the Government have agreed upon the price fixed in Article - hereof for the first period. The Contracting Officer hereby finds that the provisions of this contract are adequate to prevent excessive profits hereunder during the first period without any renegotiation pursuant to section

3 Where it will be unduly difficult for the Contractor to submit the data in the form specified in paragraphs (i) and (ii), the following form may be substituted for these paragraphs, if the Contracting Officer is satisfied that it will provide reliable and sufficient data for the purposes of the article:

(i) Revised estimates of the cost of performing the entire contract, based upon the cost experience of the Contractor during the trial run and upon all other relevant factors, itemized in the same way as the estimated cost stated in section (b) above, and showing separately any reserves for-contingencies included in the stimate."

Paragraph (iii) will then be renumbered (ii). 
403, the Sixth Supplemental National Defense Appropriation Act, 1942, as amended. The Contractor and the Government therefore agree that the prices fixed in Article - hereof shall be paid for items delivered hereunder during the first period and that such prices for that period shall not be subject to renegotiation under said statute as amended or Article - hereof.

(c) Periodic statements. Fifteen days before the end of each period hereunder, except the last, or at such other time or times as the Contracting Officer may fix, the Contractor will submit to the Contracting Officer the following data-

(I) Statements showing the actual cost of producing all items completed for delivery during such period, for which cost figures are available, and such other statements as the Contracting Officer may require.

(2) Estimates of the cost of items to be delivered during the next succeeding period, based upon the previous cost experience of the Contractor and upon all other relevant factors.

(3) Proposed prices for items to be delivered during the next succeeding period.

(d) Periodic price adjustment-exemptions.

(I) Upon the filing of the data required by section (c) hercof, the Contractor and the Contracting Officer will negotiate in good faith to agree upon adjusted cost estimates and prices for items to be delivered during the next succeeding period under this contract.

(2) Prices so negotiated and agreed upon may be in excess of or less than the prices stated in Article - hereof. In negotiating such prices consideration will be given to all pertinent factors which have affected the Contractor's costs for items delivered hereunder during any preceding period, or which are likely to affect such costs for items to be delivered hereunder during the next succecding period, and to all pertinent factors bearing upon the profit margin which is reasonable for the Contractor to earn during the succeeding period. Whenever the Contractor, by skillful management, careful buying, or efficiency in production, has reduced costs experienced during the next preceding period below the estimated amount thereof, and the Government will benefit therefrom by reduced prices from the succeeding period, the contemplated margin of profit for the succeeding period may be increased in recognition of these facts.

(3) After each negotiation, the agreement reached will be evidenced by a supplemental agrecment to this contract stating the cost estimates and adjusted prices for the succeeding period. In the discretion of the Contracting Officer, the supplemental agreement may contain a finding that the provisions of this contract and said supplemental agreement are adequate to prevent excessive profits during the applicable succeeding period, and an agreement that the prices fixed for such period will not be subject to rencgotiation under section 403, the Sixth Supplemental National Defense Appropriation Act, 1942, as amended, or under Article - hereof.

(4) A disagreement between the Contracting Officer and the Contractor as to an adjusted price for any period will not be subject to Article - (Disputes), and during that period the Contractor shall bc paid the price fixed for the preceding period.

(e) Payments. During the first period the Government shall pay to the Contractor the price set forth in Article - for all items delivered. During each succecding period the Government will pay to the Contractor the prices negotiated hereunder for items delivered in that period. If the price for any succecding period hereunder is still under negotiation and not agreed upon at the beginning of that period, then until an adjusted price for that period is agreed upon, the Contractor will be paid the price fixed for the last preceding period; but after the Contractor and Contracting Officer have agreed by supplemental agrcement upon the adjusted prices, an amount equal to the difference between the prices paid on the items delivercd in that priod and such adjusted prices will be added to or deducted from payments for subsequent deliveries under this contract or will be paid by or returned to the Government, as the Contracting Officer may direct.

(f) Accounts and records-statements. [The first part of this paragraph is identical to sub-paragraph (c) (2) of the Redetermination Article, supra, except that it omits the last 7 words in the first sentence therein. ED.] The Contractor represents that the estimates of future costs contained in paragraph (b), and hereafter submitted pursuant to paragraph (c)(2) reflect the best judgment of the Contractor as to probable costs on the basis of previous cost experience and all other relevant factors, and contain no provisions for reserves or allowances not revealed therein. 